\title{
Chloroplast «cryptic» promoter can be activated upon their transfer to plant nuclear genome
}

\author{
N. V. Grgzelyak*, A. P. Galkin, L. V. Gening, , T. V. Medvedeva, \\ L. G. Lioshina, O. V. Bulko, K. G. Gasaryan \\ Institute of Bioorganic and Petroleum Chemistry, National Academy of Sciences of Ukraine \\ 5 Murmanskaya str., Kiyv, 252660, Ukraine \\ ${ }^{1}$ Institute of Molecular Genetics, Russian Academy of Sciences \\ 46 Kurchatov sq., Moscow, 123182 , Russia
}

\begin{abstract}
It is shown that a DNA fragment containing the previouslydescribed exon 2 sequence of the chloroplast gene for ribosomal protein $S 12$ can determine expression of the reporter npt-II gene in transgenic plant nuclear genome. Transcription start points in the transgenic plant were localized within the rpS 12 DNA coding sequences. After $5^{\prime}-r p S 12-C A T-n o s-3^{\prime}$ gene construction has been introduced to tobacco protoplasts by PEG-treatment. chloramphenicol acetyltransferase (CAT) enzyme activity was detectable by transient assays. These facts indicate that "cryptic" promoter-like sequences exist in chloroplast genome which can be activated as a result of their artifical or natural transfer to the nuclei.
\end{abstract}

Introduction. Evolutionary gene transfer from chloroplast to nuclear genomes is a corner-stone of the now widely accepted endosymbiotic theory [1].

Many of the genes encoding proteins integral to plastid metabolism which were originally encoded in the chloroplast genome are thought to have been transfered to the nucleus during the course of plant evolution. Indeed, a number of evident examples of intracellular gene «migration» from chloroplast to nuclei have been reported $[2-4]$.

As such movement of a gene has recurrently occured along plant evolution, then the most of the plastid genes have homologous counterparts in the nucleus, where they were found as short $(<1.0 \mathrm{~kb}$ ) or long (several kb) sequences [5] Evidently, these sequences in nuclear DNA don't differ markedly from those in plastome DNA [6, 7]

The DNA sequences that move between different genomes of the cell are a good tool to analyse mechanisms involved in this process and to understand the consequences of such transfer. As gene transfer is a currently routine technique for many plant species, it may be used for studies modelling some natural mechanisms of the genetic flux.

In our previous papers plant DNA segments with transcription-promoting activity were selected from a pool of random tobacco nuclear DNA fragments [8]. One of the isolated DNA fragments cloned in $p D N t 23$ plasmid was further studied in detail. It was sequenced and transgenic plants containing npt-ll gene downstream this DNA segment were regenerated [9].

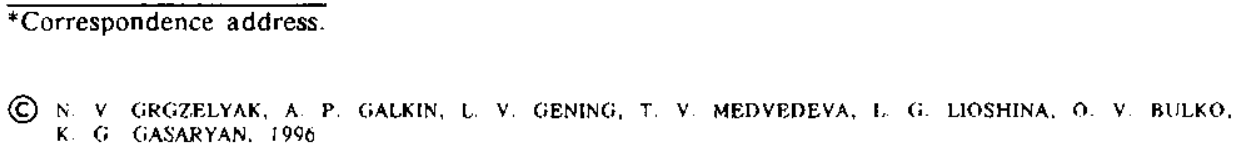


In this paper we report that this DNA fragment represents the exon 2 of the chloroplast gene for ribosomal protein $S 12(r p S / 2)$ with flanking sequences and present an evidence that when this fragment may occur to be located in front of some structural gene, new patterns of the gene regulation could arise due to the «cryptic» controlling elements upon transfer to the plant nuclear genome.

Materials and Methods. Isolation and analysis of nucleic acids from plants. Plant DNA was obtained from cell nuclei of green leaves $[10]$. Chloroplast DNA was purified by phenol-chlorophorm deproteinization $111 \mathrm{l}$. Total RNA from plants was obtained by centrifugation through $\mathrm{CsCl}[12]$. The 5 -ends of transcripts were mapped by SI nuclease technique [13].

Cloning and analysis of constructed plasmids. Restriction digests, ligations, transformations, DNA labelling and plasmid preparation were done by standard methods [14].

DNA sequence data were analysed in an IBM-PS AT computer using the «DNA-STAR» and «PCGENE» software packages.

Protoplast isolation and DNA transfer. Leaf protoplasts of Nicotiana tabacum cv. Petit Havana SR1 were isolated from aseptically grown plants and transformed as described previously [15].

The dividing protoplasts were allowed to develop for 3 weeks without selection and then kanamycin was added to a concentration of $150 \mathrm{mg} / 1$. After approximately 6 weeks in culture individual colonies growing in the selective medium were visible and were picked onto agar-solidified media containing kanamycin. A total of 27 colonies were recovered from the transformed protoplasts and 54 from the positive control. However, these colonies showed marked differences in their growth on the solidified media, therefore two well proliferating calli were cut into pieces and transfered to agar medium containing $2 \mathrm{mg} / 1 \mathrm{BAP}, 0,2 \mathrm{mg} / 1 \mathrm{IAA}, 2 \%$ sucrose, $150 \mathrm{mg} / 1 \mathrm{kanamycin}$ to stimulate morphogenesis. Seven plants were regenerated and used in further studies.

In transient expression assays plasmid DNA was introduced into tobacco protoplasts by the method of $[16]$.

Enzyme assays. Assays for npt-II were performed by a modification of [17] as described by [18]. CAT activity were determined according to [19]. Each gene construction was assayed at least for 3 times.

Results and Discussion. Characterization of the pDNt23 clone. In order to find out whether the cloned sequence represents tobacco DNA, labelled $p D N t 23$ plasmid was hybridized to tobacco genomic and chloroplast DNA cut with the restriction enzyme.

As the DNA insert of the $p D N t 23$ hybridized to both ctDNA and nDNA, we decided to compare its nucleotide sequence to the published ctDNA sequence using the «DNA-STAR» computer search program. It was found that the 470 bp insert of $p D N t 23$ had $100 \%$ homology with the EcoRI-BglII fragment of the published tobacco chloroplast DNA sequence. It includes the exon 2 sequence of the gene for $r p S / 2$ and flanking sequences. Homology begins at a nucleotided 100478 and extends to a nucleotide of 100948 . Another homology region extends from a 141580 nucleotide up to nucleotide 142050 [20].

Thus, the ctDNA contains two copies of this sequence cloned, in each segments of the inverted repeat apiece.

NPT-II activity in transgenic plants. To test whether a cloned $r p S / 2$ fragment could initiate transcription in the regenerated plants and to prove that the kanamycin resistance of plant is due to the expression of chimeric npt-II gene the $p D N t 23$ plasmid was introduced into tobacco protoplasts by a direct gene transfer method $[15]$ and transgenic plants were regenerated.

To determine whether the cloned tobacco DNA fragment could direct non-tissue-specific expression or whether this expression is only tissue-specific, 

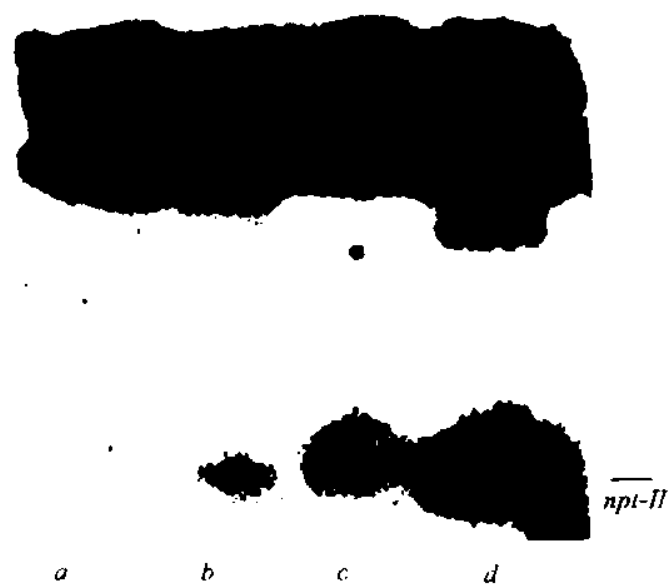

Fig. 1. Comparison of the npt-H activity in different plant organs of the transgenic plant: $a$ - leaves; $b$-stem; $c$ - roots of transgenic plant carrying the $p D N t 23$ plasmid; $d$-leaves of the transgenic plant with the $p L G V 23$ neo plasmid [21]

npt-II activities werc analysed in leaf, stem and root extracts of the transgenic plant. Transgenic plant carrying the $p L G V 23 n e o$ plasmid served as a positive control [21]. In the last case the npt-II activity was determined only in leaves for the nos promoter is known to function constitutively in all the plant organs. The results are presented in Fig. 1. As can be seen, the expression of the chimeric npt-II gene product revealed highest activity in roots, followed by the stem and near background activity in leaf tissue.

Mapping of the $5^{\prime}$-ends of transcripts synthesized in tobacco. The presence of the npt-11 activity in the transgenic plant extracts indicates the production of npt-II messenger in plant cells and can be explained either by transcriptional read through or transcription initiation at the $r p S / 2$ sequence. To distinguish between these possibilities, we mapped the $5^{\prime}$-ends of the corresponding transcripts synthesized in transgenic tobacco.

For hybridization with the total mRNA of the transgenic plant, containing the chimeric npt-II gene we used the $E c o R I-B g l I I$ fragment labelled with ${ }^{32} \mathrm{p}$ at the $5^{\prime}$-end of the $B g l I I$ restriction site. After hybridization with plant mRNA and S1 nuclease treatment of the hybrid we found two fragments protected from hydrolysis. The calculated length of the protected fragments locates the transcription start points between 146 and 149 nucleotides upstream from the BgllI restriction site (Fig. 2). The first nucleotides in both cases are the guanines.

These results indicate that transcription start points of the corresponding mRNAs in transgenic plant are localized within the rpS12 DNA fragment.

In order to find out whether the cloned fragment is transcribed in

Fig. 2. Mapping of the $5^{\prime}$-ends of transcripts in tobacco cells: $a$ - fragments, protected from $\mathrm{S} 1$ nuclease hydrolysis by total mRNA isolated from tobacco transgenic plant, carrying $p D N t 23$ plasmid; $b-$ control DNA ladder. Number on the right indicate the lengtins of the marker fragments

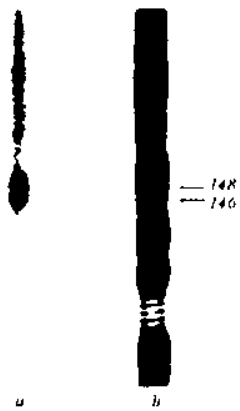


nontransgenic plants we also hybridized nick translated $p D N t 23$ DNA with total RNA isolated from tobacco plant. It is interesting that no hybridization patterns were observed in this case.

Ttansient assay in tobacco protoplasts. It may also be assumed that transcription initiation at $r p S 12$ DNA fragment in transgenic plant can be caused by position effect. In other words the $r p S 12$ fragment alone could lack the ability to initiate transcription and could be functionally active only if flanked by some regulatory sequences.

To rule out this possibility we inserted $r p S 12$ DNA fragment in front of the CAT gene and tested its ability to initiate transcription by transient assay in tobacco protoplasts. In this case the influence of nuclear $r p S 12$ flanking sequences is completely eliminated.

The presence of CAT activity in transformed tobacco protoplasts confirms the ability of the cloned fragment to confer expression in plant cells (Fig. 3).

We have found that the previously isolated and characterized DNA fragment from the $p D N t 23$ plasmid represents the 3 '-part of the chloroplast gene for $r p S 12$. It consists of exon 2 of the $r p S 12$ gene together with its flanking sequences.

The $r p S 12$ gene is known as a «divided» gene because its 5 'part is located $28 \mathrm{kbp}$ downstream from the exon 2 in $I_{\mathrm{b}}$ on the same strand or $86 \mathrm{kbp}$ downstream the $3^{\prime}$-part in $\mathrm{IR}_{\mathrm{a}}$ on the opposite strand $[20,22,23]$. Nevertheless, it is unknown whether this fact relates to the found ability of the cloned fragment to initiate transcription.

Comparison of the cloned $r p S 12$ DNA with sequences registered in the EMBL DNA database revealed strong homology between analysed fragment cloned in $p D N t 23$ and corresponding $r p S 12$ regions in chloroplasts of maize, rice, soybean, livewort etc. Moreover, we also found a high degree $(96 \%)$ of sequence homology between cloned $r p S I 2$ tobacco DNA and variable copy number DNA sequences from the rice embryo genome [24]. Copy number of this sequence changes during rice cell redifferentiation and growth and the authors suggests that these and other sequences on the inverted repeat structure of chloroplast DNA may have the character of a movable genetic element.

In view of this data, it may be reasonable to assume that the ability of $r p S 12$ DNA fragment to initiate transcription can bring in new gene regulation patterns upon its integration in front of structural nuclear gene. Positive results of such intracellular gene transfer have been reported [2].

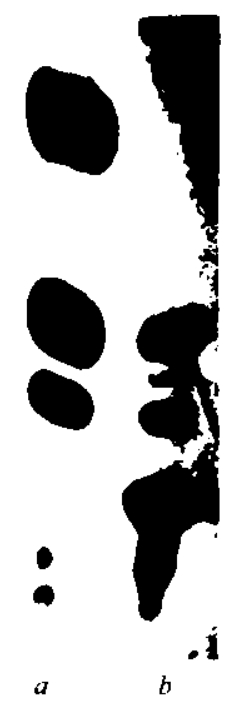

Fig. 3. CAT activity in plant protoplasts transformed with $p D N+23$ plasmid: $a-$ CAT activity in Escherichia coli cells, used as a marker for acetylated forms of ${ }^{14} \mathrm{C}$-chloramphenicol; $b-\mathrm{CAT}$ activity in tobacco protoplasts transformed with $p D N t 23$ plasmid 
Our experiments demostrate that insertion of this sequence in front of the reporter npt-II gene lead to the organ-specific expression of the chimeric npt-II gene. It is, of course, improbable, that the rpS/2 fragment contains the necessary cis-elements for tissue-specific expression. So, one can assume that this may be due to the site of $r p S 12$ DNA integration in the nuclear genome. Unfortunately, we couldn't study this phenomenon more carefully because all transgenic plants used in these experiments were probably originated from one callus.

In order to verify whether the npt-II activity in transgenic plants is due to the specific character of the cloned $r p S / 2$ DNA fragment we have mapped the 5 -ends of the mRNA transcripts in transgenic plant. The $\mathbf{S 1}$ nuclease protection data clearly indicate that transcription start points for the chimeric npt-II gene are localized within the rpS12 DNA fragment.

An analysis of the $r p S 12$ sequence shows that the nearest perfect eukaryotic TATA-box is located at position $(-115 \mathrm{bp})$ from the transcription start in plant cells.

This is too far to be recognized by the RNA polymerase II Iranscription complex, because in plants TATA-box is located at a average distance of $32+7$ bp upstream from the transcription start points [25]. However, there are a number of eukaryotic genes which do not contain TATA-boxes in the promoters, but the regulation mechanisms of these genes are still unclear [26]. No final conclusions can therefore be drawn concerning the mechanism of transcription initiation by the $r p S 12$ DNA fragment.

The results described in this report indicate that although the $r p S / 2$ DNA fragment is not a classical promoter, it can be recognized by eukaryotic RNA polymerase. Recently, the same properties have been shown for plastid psbA promoter of tobacco [27].

In conclusion, our results allow to suggest that «cryptic» regulatory elements exists in chloroplast or perhaps in nuclear genome which can be activated as a result of their translocation. Though in our experiments the role of the natural genetic flux was modelled by gene transfer technique, we can assume that natural DNA integration occures during artificial genetic transformation [28].

The role of such translocation events in evolution and the frequency of the occurance of «cryptic» controlling elements within plant genomes remain to be determined.

Н. В. Гржеляк, А. П. Галкін, Л. В. Генінг, Т. В. Медвєдєва, Л. Г. Льошина, О. В. Булко, К. Г. Газарян

Активація хлоропластних «криптичних» промоторних послідовностей при переносі ї $\mathrm{y}$ рослинний ядерний геном

Резюме

Фрагменти рослинной ДНКктонували перед кодуючою послідовністю безпромоторного ссна неоміцинфосфотрансферази-لІ і віббирали ті з них, ичо мали властивість ініціювати транскрипцію у боктеріальних клітинах. Блот-сібридизація і аналіз нуклеотидної послідовності показали, ицо фан з клонованих фрагментів відповідає 3'-кінцевій частині хлоропластного гена рибосомного білка S12 (рбS/2). При введенні генної конструкції 5'-р6S/2-XAT-nos-3' у протопласти тютюну' за допомогою обробки ПЭГом у пробах виявлялася активність ферменту хлорамфеніколаиетилтрансферази (XАT). Ці факти свідчать про те, що промотороподібні “криптичні" послідовності, які знаходяться у хлоропластному геномі, мохуть бути активовані внаслідок іх итучного або природносо переносу у ядерний геном. 
GRCiZELYAK N. V. ET AL

Н. В. Гржеляк, А. П. Галкин, Л. В. Генинг, Т. В. Медведева, Л. Г. Лешина, О. В. Булко, К. Г. Газарян

Активация хлоропластных «криптических» промоторных последовательностей при переносе их в растительный ядерный геном

Резюме

Фрагменты растительной ДНК клонировали перед кодирующей последовательностью беспромоторного гена неомицин-фосфотрансферазы-II и отбирали те из них, которые имели способность инициировать транскрипцию в бактериольных клетках. Блот-сибридизация и анализ нуклеотидной последовательности показали, что один из клонированных фрагментов соответствует 3 '-кониевой части хлоропластного гена рибосомного белка $S 12$. При введении генной конст рукци 5' -р6S 12-XAT-nos-3' в протопласты табака с помощью обработки ПЭГом в пробах обнаруживалась активность фернента хлорамфениколацетилтрансферазы ( $Х A T)$. Эти факты свидетельствуют о том, что промотороподобные "криптические» последовательности, которые находятся в хлоропластном геноме, мосут быть активированы вследствие их искусственносо или природного переноса в ядерный геном.

\section{REFERENCES}

1. Weeden N.F. Genetic and biochemical implications of the endosymbiotic origin of the chloroplasts // J. Mol. Evol. -1981.-17.-P. 133-139.

2. Pichersky E., Tankley S. D. Chloroplast DNA sequences integrated into an intron of a tomato nuclear gene $/ / \mathrm{Mol}$. and Gen. Genet.-1988.-215.-P. 65-68.

3. Baldauf $S$. L., Palmer J. D. Evolutionary transfer of the chloroplast tufA gene to the nucleus //. Nature.-1990.-344.-P. 262-265.

4. Oliver J. L., Marin A., Martinez-Zapater J. M. Chloroplast genes transferred to the nuclear plant genome have adjusted to nuclear base composition and codon usage // Nucl. Acids Res. $-1990 .-18 .-P .65-73$.

5. Du Jardin P. Homologies to plastid DNA in the nuclear and mitochondrial genomes of potato $/ /$ Theor. and Appl. Genet.-1990.-79.-P. 807-812.

6. Timmis $J, N$. Scott $N$. S. Sequence homology between spinach nuclear and chloroplast genomes // Nature.-1983.-305.-P. 65-67.

7. Cheung $W . J ., S$ cott $N . S$. A continuous sequence in spinach nuclear DNA is homologous to three separated sequences in chloroplast DNA // Theor. and Appl. Genet.-1989.-77.P. $625-633$

8. Domansky N. N., Gening L. V., Galkin A. P. et al. Cloning of the Nicotiana tabacum nuclear DNA sequences that work like promoters in Escherichia coli cells // Докл. Ахад. наук CCCP.-1986.-291.-C. 1004-1008.

9. Domansky N. N., Gening $L . V .$, Kovalenko P. G. et al. Cloning of the DNA fragment that has promoter properties in the transgenic plants // Молекуляр. биология.-1989.-23.C. $1391-1399$.

10. Lichtenstein C. P., Draper J. Genetic engineering of plants DNA cloning / Ed. D. M. Glover.Oxford: IRL press, 1986.-Vol. 11.-P. 107.

11. Bookjons G., Stumman B. M., Henningsen $K$. W. Preparation of chloroplast DNA from pea plastids isolated in a medium of high ionic strength // Anal. Biochem. - 1984._141.—P. 244247.

12. Chirgwin J. M., Przybyla A. E., McDonald R. J. et al. Isolation of biologically active ribonucleic acids from sources enriched in ribonuclease // Biochemistry.-1979.-218.-P. 5294-5299.

13. DiRita $V . G$., Gelvin $S$. B. Deletion analysis of the mannopine, synthase gene promoter in sunflower crown gall tumors and Agrobacterium tumefasience $/ / \mathrm{Mol}$. and Gen. Genet.1987.-207.-P. 233-241.

14. Maniatis $r$., Fritsch E. E., Sambrook J. Molecular cloning: a laboratory manual.- New York: Cold Spring Harbor Lab., 1987.-352 p.

15. Shillito R. D., Saul M.W., Paszkowski J. et al. High efficiency direct gene transfer to plants // Bio/Technology.-1985.-3.-P. 1099-1103

16. Prols $M$., Topfer $R$., Shell J., Steinbiss $H . H$. Transient gene expression in tobacco protoplasts 1. Time course of CAT appearence // Plant. Cell. Rep. -1988.-7.-P. 221-224.

17. Reiss B., Sprengler $R$., Will $H$. , Schaller $H$. A new sensitive method for qualitative and quantitative assay of neomycin phosphotransferase in crude cell extracts // Gene.-1984.30.-P. $211-218$.

18. Schreier P. H., Sefton E. A., Schell J., Bohnert H.J. The use of nuclear encoded sequences to direct the light-regulated synthesis and transport of foreign protein into plant chioroplasts $/ /$ EMBO J. - 1985.-4.-P. 25-32. 
19. Odell J. T., Knowlton S., Lin W., Mauvais C. J. Properties of an isolated transcription stimulating sequence derived from the cauliflower mosaic virus $35 \mathrm{~S}$ promoter // Plant. Mol. Biol.-1988.-10.-P. 263-272.

20. Shinozaki $K$., Ohme $M$., Tanaka $M$. et al. The complete nucleotide sequence of the tobacco chloroplast genome: its gene organization and expression // EMBO J.-1986.-2.-P. 987995.

21. Herrera-Estrella $L$, De Block M., Messens $E$. et al. Chimeric genes as dominant selectable markers in plant cells // Ibid.-1983.-2.-P. 987-995.

22. Torazawa $K$., Hayashida $N$., Obokata $J$. et al. The $5^{\prime}$-part of the gene for ribosomal protein $S / 2$ is located $30 \mathrm{kbp}$ downstream from its $3^{\prime}$-part in tobacco chloroplast genome // Nucl. Acids Res. -1986.-14.- P. 3143.

23. Zaita N., Torazawa $K$., Shinozaki $K$., Sugiura $M$. Trans splicing in vivo: joining of transcripts from the «divided" gene for ribosomal protein $S / 2$ in the chloroplasts of tobacco // FEBS Let.-1987.-210.-P. 153-156.

24. Kikuchi $S$., Takaiva $F$., Oono $K$. Variable copy number DNA sequences in rice // Mol. and Gen. Genet.-1987.-210.-P. 373-380.

25. Messing J., Geraghty D., Heidecker G. et al. Plant gene structure // Eds T. Kosuge, C. P. Meredity, A. Hollaender. $\rightarrow$ New York: Plenum press, 1983. $\rightarrow$ P. $211-227$

26. Dynan W. S. Promoters for housekeeping genes // Trends Genet.-1986.-4.-P. 196-197.

27. Cornelissen $M$. Vandewiele $M$. Nuclear transcription activity of the tobacco plastid psbA promoter // Nucl. Acids Res. -1989.-17.-P. 19-28.

28. Pichersky E., Logsdon J. M., Jr., McGrath J. M., Stasys R. A. Fragments of plastid DNA in the nuclear genome of tomato: prevalence, chromosomal location, and possible mechanism of integration // Mol. and Gen. Genet.-1991.-225.-P. 453-458. 